\title{
Kombinasjon av fire livsstilsfaktorer kan gi risiko for slag
}

Utvalg og oversettelse ved Liv Merete Reinar

Illustrasjonsfoto: Monkey Business/ Scanpix

Påvirker en kombinasjon av fire livsstilsfaktorer (røyking, fysisk aktivitet, alkoholbruk og inntak av frukt og grønt) risikoen for slag hos hjemmeboende personer?

\section{METODE}

Design

Kohortstudie med gjennomsnittlig 11,5 års oppfølging (Norfolk component of the European Prospective Investigation of Cancer (EPIC-Norfolk).

\section{Setting}

Allmennpraksis i England.

\section{Deltakere}

20040 personer som var mellom 40-79 år (gjennomsnittsalder 58 år, 55 prosent kvinner) uten kjent hjerteinfarkt eller slag.

\section{Risikofaktorer}

Røyking, fysisk aktivitet, alkoholbruk og inntak av frukt og grønnsaker. Deltakere fikk ett poeng hver for å være ikkerøyker, være fysisk aktiv, moderat bruk av alkohol (1-14 enheter per uke), og spise $\geq$ porsjoner med frukt og grønnsaker per dag (blodkonsentrasjon av vitamin C $\geq 50 \mu \mathrm{mol} / \mathrm{l}$ ).
Utfall: innsidens av slag (sykehus journal eller dødsattest). Resultatene ble justert for alder, kjønn, kroppsmasseindeks, systolisk blodtrykk, kolesterol, aspirinbruk, diabetes og sosial klasse.

\section{HOVEDRESULTATER}

599 slag (168 fatale) ble registrert i oppfølgingstiden. Risiko for slag økte ved hvert poeng trukket fra i en kombinert livsstilsskår (tabell).

\section{KONKLUSJON}

En kombinasjon av fire livsstilsfaktorer (røyking, lav fysisk aktivitet, alkoholbruk > to standarddrinker per dag, og lavt forbruk av frukt og grønt) var assosiert med økt risiko for slag.
Sammendrag fra: Myint PK, Luben RN, Wareham NJ, et al. Combined effect of health behaviours and risk of first ever stroke in 20040 men and women over 11 years' follow-up in Norfolk cohort of European Prospective Investigation of Cancer (EPIC Norfolk): prospective population study. BMJ 2009;338:b349.

Korrespondanse: Dr. PK Myint, University of East Anglia, Norwich, UK: phyo.k.myint@uea. ac.uk

Finansiering: Cancer Research UK; Medical Research Council; Stroke Association; British Heart Foundation; Research Into Ageing; academy of Medical Sciences; Wellcome Trust.

\begin{tabular}{|c|c|c|c|}
\hline $\begin{array}{l}\text { Antall } \\
\text { faktorer }\end{array}$ & $\begin{array}{l}\text { Justert RR } \\
(95 \% \mathrm{KI}) \text { for alle** }\end{array}$ & $\begin{array}{l}\text { Justert RR } \\
\text { (KI) for menn** }\end{array}$ & $\begin{array}{l}\text { Justert RR } \\
\text { (KI) for kvinner** }\end{array}$ \\
\hline 3 & $1,15(0,89$ til 1,49$) \sim$ & $1,04(0,71$ til 1,53$) \sim$ & $1,20(0,85$ til 1,70$) \sim$ \\
\hline 2 & $1,58$ (1,22 til 2,05$)$ & $1,33(0,91$ til 1,96$) \sim$ & $1,80(1,27$ til 2,56$) \sim$ \\
\hline 1 & $2,18(1,63$ til 2,92$)$ & $1,79(1,16$ til 2,74$) \sim$ & $2,53(1,70$ til 3,77$) \sim$ \\
\hline 0 & $2,31(1,33$ til 4,02) & $1,45(0,61$ til 3,45$) \sim$ & $3,40(1,66$ til 6,96$) \sim$ \\
\hline
\end{tabular}

* RR sammenlignet 0-3 faktorer med 4 faktorer; livsstilsfaktorene var ikke-røyking, være fysisk aktiv, alkoholbruk 1-14 enheter per uke, og å spise $\geq 5$ porsjoner frukt og grønt (blodkonsentrasjon av vitamin $\mathrm{C} \geq 50 \mathrm{\mu mol} / \mathrm{l}$.

**Justert for alder, kjønn, kroppsmasseindeks, systolisk blodtrykk, kolesterol, aspirinbruk,

diabetes og sosial klasse.

- Ikke statistisk signifikant. 


\section{EVIDENCE BASED NURSING}

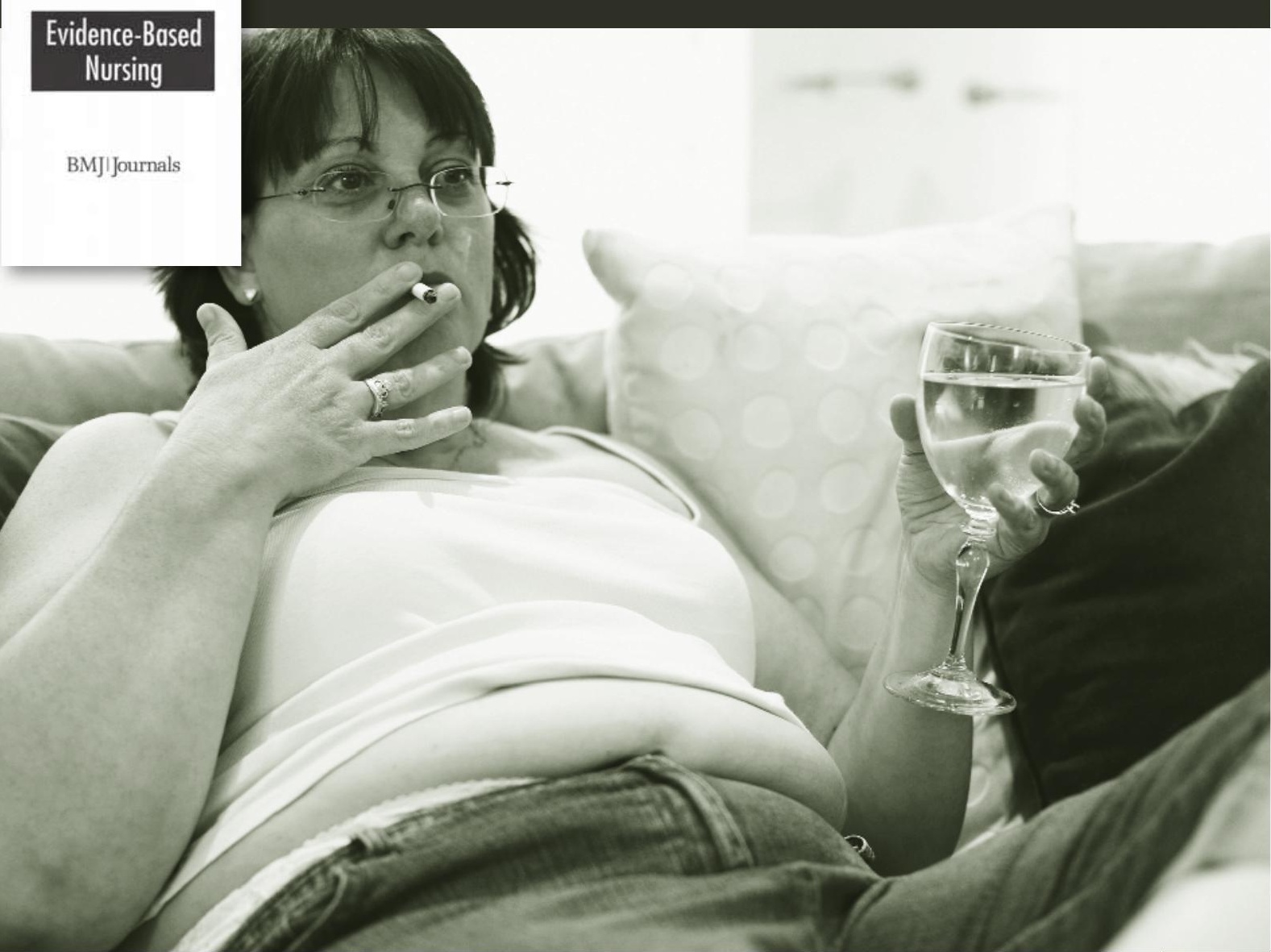

Livsstilsfaktorer som røyking, fysisk aktivitet, alkoholinntak og kosthold har blitt assosiert med insidensen av slag. Forskning som har studert hvordan en kombinasjon av disse faktorene virker inn er begrenset. Denne studien til Myint og medarbeidere er en av få studier som har kvantifisert den kombinerte effekten av denne typen atferd på risiko for slag. De viser at tilstedeværelsen av disse fire faktorene resulterte i en fordobling i forskjell på insidensen av slag. Styrken i denne studien er at den er prospektiv longitudinell, som er riktig for denne typen forskningsspørsmål, stort utvalg, bruk av sykepleiere i helseundersøkelsene, og at det er justert for mange potensielle forvekslingsfaktorer. Plasma vitamin C konsentrasjon gir et objektivt mål for inntak av frukt og grønt når det sammenlig- nes med selvrapportering av kosthold, som ellers kan være påvirket av «social desirability» bias. Bakgrunnsinformasjon om validiteten av plasma vitamin C konsentrasjon som surrogatmarkør for frukt- og grøntkonsum kunne vært nyttig. Det må vises forsiktighet når resultatene fra denne studien generaliseres til andre etniske grupper og grupper med ko-morbiditet. Fordi ikke alle deltakerne møtte til helsesjekk underveis i studien var det en skjevhet mot de friskeste deltakerne Imen denne skjevheten vil heller svekke assosiasjonen enn å overestimere den). Eksklusjon av omtrent 9000 deltakere på grunn av manglende data førte til at noen analyser ikke ble utført. Selv om forskerne ikke fant forskjell mellom inkluderte og ekskluderte deltakere så kan forskjeller i karakteristika som ikke ble undersøkt påvirke resultatene. Funnene fra denne studien er relevant for sykepleiere som jobber med oppfølging av pasienter fra nevrologi og hjertemedisin og i rehabilitering, for sykepleiere i kommunehelsetjenesten som jobber mot voksen og eldre og for sykepleiere som er involvert i forebyggende helsearbeid. Spesialsykepleiere som jobber med voksne og eldre i primær- eller spesialisthelsetjenesten vil også ha nytte av disse resultatene. Selv om den relative effekten av de ulike faktorene ikke er vurdert så har pasienter flere å velge blant dersom de ønsker å redusere også sin risiko. Funnene antyder at atferdsendring ikke trenger å stoppe ved ett tiltak.

Angela de Guzman, RN (EC), PHCNP, MScN. Toronto, Ontario, Canada.

(C) Evidence Based Nursing (EBN) oktober 2009 Vol 12 nummer 4. 